\title{
Pengaruh Pajak Daerah, Retribusi Daerah, terhadap Kemampuan keuangan Daerah Kabupaten Gorontalo
}

Saprudin

Prodi Akuntansi, Fakultas Ekonomi, Universitas Gorontalo Email: saprudin545@gmail.com

Abstract
This study aims to identify, analyze, test and provide empirical
evidence as to what the relationship variables Local Taxes, Levies, on
Financial Capability.
Type This research is associative which aims to determine the
relationship between two or more variables, relations who want to
study in this study is causal (causal) to analyze the relationships
between the variables with other variables and how a variable affects
other variables.
Research Shows that one). Local Taxes positive effect on the
ability of the Regional Financial Daerah.2). Retribution positive effect
on the ability of the Regional Local Finance rejected. Levies according
to Law No. 34 of 2000 is local charges as payment for specific services
or special licensing is provided and / or supplied by the local
government for the benefit of private persons or entities. Equal to the
tax, retribution is also a positive influence on the Regional Financial
Capability area.
Keywords: Local tax, Retribution, Financial Capability.

\section{PENDAHULUAN}

Sejak Januari 2001 telah terjadi perubahan yang cukup fundamental dalam mekanisme penyelenggaraan pemerintahan di Indonesia. Perubahan tersebut terutama terkait dengan dilaksanakannya "secara efektif" otonomi daerah sebagaimana yang diamanatkan dalam UU Nomor 22 Tahun 1999 tentang pemerintahan daerah yang telah direvisi dengan UU Nomor 32 Tahun 2004 dan UU Nomor 25 Tahun 1999 tentang perimbangan keuangan antara pemerintah pusat dan daerah yang telah direvisi dengan UU Nomor 33 Tahun 2004. Kedua UU di bidang otonomi daerah tersebut telah menetapkan pemberian kewenangan otonomi dalam wujud otonomi yang luas, nyata, dan bertanggung jawab kepada daerah.

Pelaksanaan suatu otonomi daerah yang dititik beratkan pada Daerah Kabupaten dan Daerah Kota dimulai dengan adanya penyerahan dan pengalihan 
pembiayaan, Riduansyah (2003:17). Adapun Sumber pembiayaan yang paling penting dalam pembiayaan daerah adalah Pendapatan Asli Daerah (PAD). Komponen utama dari PAD yang telah tercantum dalam Undang-Undang Nomor 33 Tahun 2004:

a. Pajak daerah;

b. Retribusi daerah;

c. Hasil pengelolaan Kekayaan daerah yang dipisahkan (BUMN/BUMD)

d. Lain-lain Pendapatan Asli Daerah yang sah.

Implementasi dari kebijakan pemerintah pusat untuk memberikan kewenangan kepada pemerintah daerah sebagai penggerak dari suatu pembangunan pada pemerintah yang paling dekat dengan masyarakat.

Dalam pelaksanaannnya Pemerintah Kabupaten Gorontalo telah menetapkan beberapa Peraturan Daerah yang tujuannya untuk memaksimalkan realisasi penerimaan Pajak daerah itu sendiri karena Pajak daerah akan optimal sebagai kontribusi PAD apabila realisasinya dapat melebihi target yang telah di tetapkan dan kemandirian daerah dapat terwujud sehingga tidak bergantung lagi kepada pusat. Adapun ketetapan mengenai Pajak dan Retribusi Daerah pada kabupaten Gorontalo diantaranya tertuang pada :

1. Perda No. 39 Tahun 2010 tentang Bea perolehan hak atas tanah dan Bangunan

2. Perda No. 1 Tahun 2011 Tentang Pajak Hotel

3. Perda No. 2 Tahun 2011 Tentang Pajak Restoran

4. Perda No. 3 Tahun 2011 tentang Pajak Hiburan

5. Perda No. 4 Tahun 2011 tentang pajak Reklame

6. Perda No. 5 Tahun 2011 tentang Pajak Penerangan Jalan

7. Perda No 6 Tahun 2011 tentang Pajak Mineral Bukan Logam dan Batuan.

8. Perda No. 1 Tahun 2013 Tentang Pajak bumi bangunan perdesaan dan perkotaan

Walaupun telah ditetapkan melalui Peraturan Daerah yang mengatur penerimaan Pajak Daerah dan Retribusi Daerah, diakui saat ini belum memadai dan hanya memiliki peranan yang relatif kecil terhadap Anggaran Pendapatan dan Belanja Daerah (APBD) Kabupaten Gorontalo. Sebagian besar pengeluaran APBD dibiayai dana alokasi dari pusat. Dalam banyak hal dana alokasi dari pusat tidak sepenuhnya dapat diharapkan menutup seluruh kebutuhan pengeluaran Daerah. Oleh karena itu, pemberian peluang untuk mengenakan pungutan baru yang semula diharapkan dapat meningkatkan penerimaan Daerah, dalam kenyataannya tidak banyak diharapkan dapat menutupi kekurangan kebutuhan pengeluaran tersebut.

Dengan melihat kondisi yang telah diuraikan maka selajutnya penulis melakukan pengkajian fokus tentang pengaruh pajak daerah, retribusi daerah, terhadap kemampuan keuangan daerah Kabupaten Gorontalo.

\section{LANDASAN TEORI DAN HIPOTESIS}

\subsection{Landasan Teori}

\subsubsection{Pajak Daerah}

Menurut Marihot P. Siahaan (2005:7), pajak daerah adalah "iuran wajib yang dilakukan oleh daerah kepada orang pribadi atau badan tanpa imbalan langsung yang seimbang, yang dapat dipaksakan berdasarka peraturan 
perundang-undangan yang berlaku yang digunakan untuk membiayai penyelenggaraan pemerintah daerah dan pembangunan daerah."

Menurut Halim (2004:67), "pajak daerah merupakan pendapatan daerah yang berasal dari pajak."

Menurut UU No 34 Tahun 2000 yang dimaksud dengan pajak daerah adalah iuran wajib yang dilakukan oleh orang pribadi atau badan kepada daerah tanpa imbalan langsung yang seimbang, yang dapat dipaksakan berdasarkan peraturan perundang-undangan yang berlaku, yang digunakan untuk membiayai penyelenggaraan pemerintahan daerah dan pembangunan daerah.

Dari beberapa pengertian di atas maka dapat disimpulkan bahwa pajak daerah adalah penerimaan daerah yang berasal dari orang pribadi atau badan yang sifatnya dapat dipaksakan (yuridis) berdasarkan peratuaran perundangundangan dan tidak ada kontraprestasi/imbalan secara langsung serta digunakan untuk membiayai pemerintah dan pembangunan daerah. Wewenang pemungutan pajak daerah ada pada pemerintah daerah yang pelaksanaannya dilakukan oleh Dinas Pendapatan Daerah.

Pajak daerah merupakan komponen dari pendapatan asli daerah, sampai saat ini.Pajak daerah memberikan kontribusi daerah terbesar bagi pendapatan asli daerah. Undang-undang No. 34 Tahun 2000 memberikan peluang kepada daerah kabupaten/kota untuk memungut jenis pajak daerah lain yang dipandang memenuhi syarat selain dari jenis pajak daerah kabupaten/kota yang telah ditetapkan. Penetapan jenis pajak leinnya ini harus benar-benar bersifat spesifik dan potensial di daerah.Hal ini dimaksudkan untuk memberikan keleluasaan kepada daerah kabupaten/kota dalam mengantisipasi situasi dan kondisi derta perkembangan perekonomian daerah pada masa mendatang yang mengakibatkan perkembangan potensi pajak dengan tetap memperhatikan kesejahteraan jenis pajak dan aspirasi masyarakat serta memenuhi kriteria yang ditetapkan. Pajak daerah harus memenuhi beberapa persyaratan antara lain:

1. Tidak boleh bertentangan atau harus searah dengan kebijaksanaan pemerintah pusat.Pajak daerah harus sederhana dan tidak terlalu banyak jenisnya.

2. Biaya administrasi harus rendah

3. Tidak mencampuri sistem perpajakan pusat maupun peraturanperaturan yang ditetapkan oleh daerah serta dapat dipaksakan

Dengan demikian, penerimaan pajak harus dilakukan secara efektif agar penyelenggaraan pemerintah daerah dan pembanguna pemerintah daerah dapat terlaksana dengan baik. Pajak derah dikatakan efektif jika: Memenuhi kriteria adil, Dapat mendorong tindakan ekonomi, Mampu menstabilkan tingkat kenaikan harga, Dapat diterima oleh seluruh lapisan masyarakat, Biaya untuk administrasi ringan dan terjangkau oleh wajib pajak.

Kebijakan pungutan pajak daerah berdasarkan peraturan daerah, diupayakan tidak berbenturan dengan pungutan pusat (pajak maupun bea dan cukai), karena hal tersebut akan menimbulkan duplikasi pungutan yang pada akhirnya akan mendistorsi kegiatan perekonomian. Hal tersebut sebetulnya sudah diantisipasi dalam UU No.18 Tahun 1997 tentang pajak daerah dan retribusi daerah sebagaimana diubah dengan UU No.34 Tahun 2000, dimana dinyatakan dalam Pasal 2 ayat (4) yang antara lain menyatakan bahwa objek 
pajak daerah bukan merupakan objek pajak pusat.

Sementara itu, apabila kita perhatikan sistem perpajakan yang dianut oleh banyak negara di dunia, maka prinsip-prinsip umum perpajakan daerah yang baik pada umumnya tetap sama, yaitu harus memenuhi kriteria umum tentang perpajakan daerah sebagai berikut:

a) Prinsip memberikan pendapatan yang cukup dan elastis, artinya dapat mudah naik turun mengikuti naik/turunnya tingkat pendapatan masyarakat.

b) Adil dan merata secara vertikal artinya sesuai dengan tingkatan kelompok masyarakat dan horizontal artinya berlaku sama bagi setiap anggota kelompok masyarakat sehingga tidak ada yang kebal pajak.

c) Administrasi yang fleksibel artinya sederhana, mudah dihitung, pelayanan memuaskan bagi si wajib pajak.

d) Secara politis dapat diterima oleh masyarakat, sehingga timbul motivasi dan kesadaran pribadi untuk membayar pajak.

e) Non-distorsi terhadap perekonomian : implikasi pajak atau pungutan yang hanya menimbulkan pengaruh minimal terhadap perekonomian. Pada dasarnya setiap pajak atau pungutan akan menimbulkan suatu beban baik bagi konsumen maupun produsen. Jangan sampai suatu pajak atau pungutan menimbulkan beban tambahan (extra burden) yang berlebihan, sehingga akan merugikan masyarakat secara menyeluruh (dead-weight loss).

Untuk mempertahankan prinsip-prinsip tersebut, maka perpajakan daerah harus memiliki ciri-ciri tertentu. Adapun ciri-ciri dimaksud, khususnya yang terjadi di banyak negara sedang berkembang, adalah sebagai berikut:

a) Pajak daerah secara ekonomis dapat dipungut, berarti perbandingan antara penerimaan pajak harus lebih besar dibandingkan ongkos pemungutannya.

b) Relatif stabil, artinya penerimaan pajaknya tidak berfluktuasi terlalu besar, kadang-kadang meningkat secara drastis dan adakalanya menurun secara tajam.

c) Tax basenya harus merupakan perpaduan antara prinsip keuntungan (benefit) dan kemampuan untuk membayar (ability to pay).

Dalam kaitannya dengan pelaksanaan otonomi daerah, maka pemberian kewenangan untuk mengadakan pemungutan pajak selain mempertimbangkan kriteria-kriteria perpajakan yang berlaku secara umum, seyogyanya, juga harus mempertimbangkan ketepatan suatu pajak sebagai pajak daerah. Pajak daerah yang baik merupakan pajak yang akan mendukung pemberian kewenangan kepada daerah dalam rangka pembiayaan desentralisasi.

Untuk itu, Pemerintah Daerah dalam melakukan pungutan pajak harus tetap "menempatkan" sesuai dengan fungsinya. Adapun fungsi pajak dapat dikelompokkan menjadi 2 (dua), yaitu : fungsi budgeter dan fungsi regulator.

1. Fungsi budgeter yaitu bila pajak sebagai alat untuk mengisi kas negara yang digunakan untuk membiayai kegiatan pemerintahan dan pembangunan.

2. Fungsi regulator yaitu bila pajak dipergunakan sebagai alat mengatur untuk mencapai tujuan, misalnya : pajak minuman keras dimaksudkan agar rakyat menghindari atau mengurangi konsumsi minuman keras, pajak ekspor dimaksudkan untuk mengekang pertumbuhan ekspor 
komoditi tertentu dalam rangka menghindari kelangkaan produk tersebut di dalam negeri.

\subsubsection{Retribusi Daerah}

Retribusi daerah adalah pungutan daerah sebagai pembayaran atas jasa atau pemberian ijin tertentu yang khusus disediakan dan/atau diberikan oleh pemerintah daerah untuk kepentingan orang pribadi atau badan. Menurut UU No 34 Tahun 2000 jenis retribusi dapat dibedakan menjadi ;

1. Retribusi Jasa Umum merupakan pungutan yang dikenakan olehdaerah kepada masyarakat atas pelayanan yang diberikan. Pelayanan yang digolongkan sebagai jasa usaha tersebut tergolong quasy goods dan pelayanan yang memerlukan pengendalian dalam konsumsinya dan biaya penyediaan layanan tersebut cukup besar sehingga layak dibebankan kepada masyarakat; misalnya : retribusi pelayanan kesehatan, persampahan, akta catatan sipil dan KTP.

2. Retribusi Jasa Usaha merupakan pungutan yang dikenakan olehDaerah berkaitan dengan penyediaan layanan yang belum memadai disediakan oleh swasta dan atau penyewaan asset/kekayaan daerah yang belum dimanfaatkan; misalnya retribusi pasar grosir, terminal, rumah potong.

3. Retribusi Perijinan Tertentu merupakan pungutan yang dikenakansebagai pembayaran atas pemberian ijin untuk melakukan kegiatan tertentu yang perlu dikendalikan oleh Daerah; misalnya IMB, Ijin Pengambilan Hasil Hutan Ikutan. yaitu :

Masing-masing jenis retribusi tersebut memiliki kriteria yang berbeda

1. Kriteria Retribusi Jasa Umum

a. Retribusi jasa umum bersifat bukan pajak dan bersifat bukan retribusi jasa usaha atau retribusi perijinan tertentu.

b. Jasa yang bersangkutan merupakan kewenangan daerah dalam rangka pelaksanaan desentralisasi.

c. Jasa tersebut memberikan manfaat khusus bagi orang pribadi atau badan yang diharuskan membayar retribusi disamping untuk melayani kepentingan dan kemanfaatan umum.

d. Jasa tersebut layak untuk dikenakan retribusi.

e. Retribusi tidak bertentangan dengan kebijakan nasional mengenai penyelenggaraannya.

2. Kriteria Retribusi Jasa Usaha

a. Retribusi jasa usaha bersifat bukan pajak dan bersifat bukan retribusi jasa umum atau retribusi perijinan tertentu.

b. Jasa yng bersangkutan adalah jasa yang bersifat komersial yang seyogyanya disediakan oleh sektor swasta tetapi belum memadai atau terdapatnya harta yang dimiliki daerah yang belum dimanfaatkan secara penuh oleh pemerintah daerah.

3. Kriteria Retribusi Perijinan Tertentu

a. Perijinan tersebut termasuk kewenangan pemerintahan yang diserahkan kepada daerah dalam rangka asas desentralisasi.

b. Perijinan tersebut benar-benar diperlukan guna melindungi kepentingan umum.

c. Biaya yang menjadi beban daerah dalam penyelenggaraan ijin tersebut dan biaya untuk menanggulangi dampak negatif dari pemberian ijin 


\section{tersebut cukup besar sehingga layak dibiayai dari retribusi perijinan. \\ 2.2.3 Kemampuan Keuangan Daerah}

Kriteria penting yang lain untuk mengetahui secara nyata kemampuan daerah dalam mengatur dan mengurus rumah tangganya adalah kemampuan daerah dalam bidang keuangan. Dengan perkataan lain, faktor keuangan merupakan faktor yang penting dalam mengatur tingkat kemampuan daerah dalam melaksanakan otonomi daerah.

Dalam Peraturan Pemerintah No. 105 tahun 2000, menyebutkan bahwa keuangan daerah adalah semua hak dan kewajiban daerah dalam rangka penyelenggaraan pemerintah daerah yang dapat dinilai dengan uang temasuk didalamnya segala bentuk kekayaan lain yang berhubungan dengan hak dan kewajiban daerah tersebut dalam kerangka APBD.

Sehubungan dengan pentingnya posisi keuangan tersebut, keuangan daerah sebagai salah satu indikator untuk mengetahui kemampuan daerah dalam mengatur dan mengurus rumah tangganya sendiri. Dengan dikeluarkannya undang-undang tentang Otonomi Daerah, membawa konsekuensi bagi daerah yang akan menimbulkan perbedaan antar daerah yang satu dengan yang lainnya, terutama dalam hal kemampuan keuangan daerah, antara lain (Nataluddin, 2001: 167):

1) Daerah yang mampu melaksanakan otonomi daerah.

2) Daerah yang mendekati mampu melaksanakan otonomi daerah.

3) Daerah yang sedikit mampu melaksanakan otonomi daerah dan

4) Daerah yang kurang mampu melaksanakan urusan otonomi daerah.

Selain itu ciri utama yang menunjukkan suatu daerah mampu melaksanakan otonomi daerah adalah sebagai berikut (Nataluddin, 2001:167):

1) Kemampuan keuangan daerah, artinya daerah harus memiliki kewenangan dan kemampuan untuk menggali sumber-sumber keuangan, mengelola dan menggunakan keuangan sendiri yang cukup memadai untuk membiayai penyelenggaraan pemerintahannya.

2) Ketergantungan kepada bantuan pusat harus seminimal mungkin agar Pendapatan Asli Daerah (PAD) harus menjadi bagian sumber keuangan terbesar, yang didukung oleh kebijakan perimbangan keuangan pusat dan daerah, sehingga peranan pemerintah daerah menjadi lebih besar.

Berkaitan dengan hakekat otonomi daerah yaitu berkaitan dengan pelimpahan wewenang pengambilan keputusan kebijakan, pengelolaan dana publik dan pengaturan kegiatan dalam penyelenggaraan pemerintah dan pelayanan masyarakat, maka peranan data keuangan daerah sangat dibutuhkan untuk mengidentifikasi sumber-sumber pembiayaan daerah serta jenis dan besar belanja yang harus dikeluarkan agar perencanaan keuangan dapat dilaksanakan secara efektif dan efisien. Data keuangan daerah yang memberikan gambaran statistik perkembangan anggaran dan realisasi, baik penerimaan maupun pengeluaran dan analisa terhadapnya merupakan informasi yang penting terutama untuk membuat kebijakan dalam pengelolaan keuangan daerah untuk melihat kemampuan / kemandirian daerah.

\subsection{Hipotesis}

Hipotesis menyatakan hubungan yang diduga secara logis antara dua variabel atau lebih dalam rumusan preposisi yang dapat diuji secara empiris. Berdasarkan uraian teori yang telah dikemukan, maka dirumuskan hipotesis 
yaitu: Apakah Pajak Daerah (PD), dan Retribusi Daerah (RD), berpengaruh terhadap Kemampuan Keuangan Daerah?.

\section{METODE PENELITIAN}

Peneliti menggunakan penelitian assosiatif yang bertujuan untuk mengetahui hubungan antara dua variabel atau lebih (Sugiyono, 2006 : 11). Hubungan yang hendak diteliti pada penelitian ini adalah hubungan sebab akibat (kausal) untuk menganalisis hubungan-hubungan antara satu variabel dengan variabel lainnya dan bagaimana suatu variabel mempengaruhi variabel lainnya (Umar, 2001 : 63).

Berdasarkan jenis masalah yang diselidiki, tempat dan waktu yang dilakukan serta teknik dan alat yang digunakan dalam melakukan penelitian maka penelitian ini digolongkan penelitian kausalitas. Data yang digunakan adalah Ex Post Facto, yaitu suatu penelitian yang meneliti peristiwa yang telah terjadi dan kemudian menuntut kebelakang untuk mengetahui faktor-faktor yang dapat menimbulkan kejadian tersebut (Sugiyanto, 2002).

Hipotesis penelitian diuji dengan menggunakan analisis regresi linier berganda dengan menggunakan uji-t dan uji-F. Metode analisis regresi linear berganda berfungsi untuk mengetahui pengaruh / hubungan dari variabel bebas dengan variabel terikat. Pengolahan data akan dilakukan dengan menggunakan alat bantu aplikasi software SPSS for windows. Model persamaan regresi untuk menguji hipotesis, dengan formulasi sebagai berikut :

$$
\mathbf{Y}=a+\beta 1 \times 1+\beta 2 \times 2+e
$$

Keterangan:

$\mathrm{Y}=$ Kemampuan Keuangan Daearah

$\mathrm{X} 1$ = Pajak Daerah

$\mathrm{X} 2=$ Retribusi Daerah

$\mathrm{a}=$ konstanta

$\beta 1, \beta 2, \beta 3=$ koefisien regresi yang menunjukan angka peningkatan atau penurunan variabel dependen berdasarkan pada variabel independen.

$\mathrm{E}=$ erroe

\section{HASIL DAN PEMBAHASAN}

\subsection{Hasil Penelitian}

\subsubsection{Statistik Deskriptif}

Statistik deskriptif adalah suatu bentuk analisis yang dipergunakan untuk mendeskripsikan data tanpa melakukan pengambilan keputusan. Deskriptif adalah suatu cara untuk mendeskripsikan variabel - variabel yang diteliti dengan cara mengkalkulasikan data sesuai kebutuhan pengguna.

Data selama 5 tahun anggaran diperoleh statistik deskriptif yang mencakup n (banyaknya data yang diperoleh) nilai minimum, nilai maksimum, rata (mean) dan standar deviasi atas variabel - variabel penelitian. Variabel tersebut meliputi Pajak Daerah, Retribusi daerah, dan Kemampuan Keuangan Daerah. Hasil analisis data dengan menggunakan program SPSS versi 21 diperoleh sebagai berikut : 
Rata - rata Retribusi daerah dari tahu 2010 - 2014 mengalami fluktuasi peningkatan dan penerimaan Retribusi yang paling besar terjadi Pajak Daeraha tahun 2012 yaitu sebesar Rp. 7.286.896.344 Namun demikian nilai standar deviasi masih cukup besar. Hal ini menunjuka adanya indikasi terjadinya kesenjangan pemerimaan daerah yaitu adanya ketimpangan fiskal yang masih tinggi.

Kemampuan Keuangan Daerah Daerah tertinggi terjadi Pajak Daeraha tahun 2013 sebesar Rp.45.982.688.930,- sedangkan yang terendah terjadi Pajak Daeraha tahun 2011 sebesar Rp. 32.690.736.000,-. Kemampuan Keuangan Daerah kabupaten Gorontalo dari tahun 2010 sampai 2014 mengalami peningkatan yag fluktuatif. Nilai standar deviasi menunjukkan adanya kesenjangan pengeluaran peningkatan Kemampuan Keuanga daerah.

\subsubsection{Analisis Regresi Berganda}

1. Koefisien Determinasi

Hasil Nilai R-Square dari regresi digunakan untuk mengetahui besarnya struktur Keuangan yang dipengaruhi oleh variabel - variabel bebasnya. Output hasil pengolahan data tertera Pajak Daeraha tabel berikut:

Tabel 1

Model Summary

\begin{tabular}{|l|r|r|r|r|r|}
\hline $\begin{array}{l}\text { Mode } \\
1\end{array}$ & $\mathrm{R}$ & $\begin{array}{c}\mathrm{R} \\
\text { Square }\end{array}$ & $\begin{array}{c}\text { Adjusted R } \\
\text { Square }\end{array}$ & $\begin{array}{c}\text { Std. Error } \\
\text { of the } \\
\text { Estimate }\end{array}$ & $\begin{array}{r}\text { Durbin- } \\
\text { Watson }\end{array}$ \\
\hline 1 &, $291^{\mathrm{a}}$ &, 085 &, 017 &, 11759 &, 479 \\
\hline
\end{tabular}

a. Predictors: (Constant), X2, X1

b. Dependent Variable: Y

Pajak Daerah pada tabel 1 menunjukkan bahwa koefisien determinasi yang ditunjukkan dari nilai R-Square sebesar 0,085 hal ini berarti 8,5\% variasi Kemampuan Keuangan Daerah dapat dijelaskan oleh variasi dari kedua variabel independen yaitu Pajak Daerah, dan Retribusi Daerah, sedangkan sisanya sebesar 91,5\% dijelaskan oleh variabel lain yang tidak dimasukkan dalam model penelitian ini

2. Uji signifikansi (Uji Statistik F)

Pengujian hipotesis $\mathrm{F}$ digunakan untuk melihat apakah secara keseluruhan variabel bebas mempunyai pengaruh yang bermakna terhadap variabel terikat. Dari pengujian secara simultan diperoleh sebagai berikut:

Tabel 2 Uji Simultan

ANOVAa

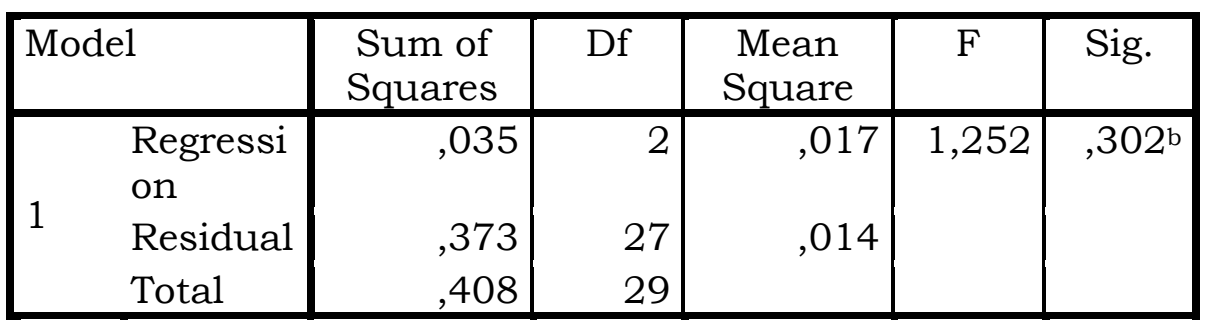

a. Dependent Variable: $Y$

b. Predictors: (Constant), X2, X1 
Berdasarkan tabel 2, hasil uji ANOVA (Analysis of Variance) diperoleh nilai $F_{\text {hitung }}$ sebesar 1,252 dengan nilai signifikansi sebesar 0,302 lebih besar dari 0,05, maka terbukti semua variabel bebas yang diamati secara serempak (simultan) tidak berpengaruh signifikan terhadap variabel terikat. Dengan demikian model regresi ini dapat menjelaskan Pajak Daerah, dan Retribusi daerah secara bersama - sama Tidak berpengaruh terhadap Kemampuan Keuangan Daerah Kabupaten Gorontalo

3. Uji Signifikansi Parameter Individual ( Uji Statistik t)

Untuk menentukan pengaruh masing - masing variabel bebast digunakan uji t. Dari hasil pengujian analisis regresi sebagaimana Pajak Daeraha lampiran diketahui nilai $t_{\text {hitung }}$ sebagai berikut

\section{Tabel 3 Uji Parsial}

Coefficientsa

\begin{tabular}{|l|r|r|r|r|r|}
\hline Model & \multicolumn{2}{|c|}{$\begin{array}{c}\text { Unstandardized } \\
\text { Coefficients }\end{array}$} & $\begin{array}{r}\text { Standardize } \\
\text { d } \\
\text { Coefficients }\end{array}$ & \multirow{2}{*}{ Sig. } & \\
\cline { 2 - 4 } & \multicolumn{1}{|c|}{ B } & Std. Error & \multicolumn{1}{|c|}{ Beta } & & \\
\hline (Constan & 23,913 &, 307 & & 77,985 &, 000 \\
t) & & & & & \\
X1 &, 015 &, 010 &, 271 & 1,465 &, 154 \\
X2 &, 006 &, 013 &, 084 &, 453 &, 654 \\
X3 &, 006 &, 013 &, 084 &, 453 &, 654 \\
\hline
\end{tabular}

a. Dependent Variable: Y

Hasil perhitungan statistik tersebut menunjukkan bahwa variabel Pajak daerah menunjukkan tingkat signifikan 0,154 yang lebih besar dari 0,05, berati tidak mempunyai pengaruh signifikan terhadap Kemampuan Keuangan Daerah daerah. demikian pula Retribusi Daerah dengan tingkat signifikansi lebih besar dari 0,05 memberikan bukti bahwa kedua variabel tersebut (Pajak daerah dan Retribusi daerah) tidak memberikan pengaruh yang signifikan terhadap Kemampauan keuangan daerah

4. Uji Persamaan Regresi berikut:

Sebagaimana dalam tabel di atas di peroleh persamaan regersi sebagai

$$
Y=23,913+0,271 X_{1}+0,084 X_{2}
$$

Dari persamaan tersebut dapata dijelaskan sebagai berikut:

a. Nilai konstanta $(\mathrm{a})=23,913$, memberikan makna jika Pajak Daerah $\left(\mathrm{X}_{1}\right)$, Retribusi Daerah $\left(\mathrm{X}_{2}\right)$, dan Dana Bagi Hasil (X3) bernilai 0, maka Kemampuan Keuangan Daerah akan bernilai akan konstan Pajak Daeraha angka 23,913.

b. Nilai koefisien regresi Pajak Daerah $\left(b_{1}\right)$ bernilai positif yaitu 0,271, memberikan arti bahwa setiap peningkatan Pajak Daerah sebesar satu satuan akan meningkatkan Kemampuan Keuangan Daerah daerah sebesar 0,271, dengan asumsi Retribusi Daerah (X2) dalam keadaan tetap.

c. Nilai koefisien regresi Retribusi Daerah $\left(\mathrm{X}_{2}\right)$ bernilai positif yaitu 0,084, memberikan arti bahwa setiap peningkatan Retribusi sebesar satu satuan 
akan meningkatkan Kemampuan Keungan sebesar 0,084, dengan asumsi Pajak Daerah $\left(\mathrm{X}_{1}\right)$ dalam keadaan tetap.

\subsection{Pembahasan}

\subsubsection{Pengaruh Pajak Daearah terhadap Kemampuan Keuangan Daerah Darah.}

Berdasarkan hasil analisis dengan menggunakan perhitungan statistik, menunjukkan nilai koefisien regresi $\mathrm{X}_{1}$ terhadap $\mathrm{Y}$ sebesar 0,271 dengan $\mathrm{t}_{\text {hitung }}=$ 3.332 dan nilai signifikansi 0,154 lebih besar dari tingkat signifikansi alpa = 0,05, hal ini berarti bahwa tidak terdapat pengaruh signifikan Pajak Daerah terhadap Kemampuan Keuangan Daerah Daerah. Bahwa adanya pengaruh positif tersebut berarti semakin tinggi Pajak Daerah, maka Kemampuan Keuangan Daerah Daerah akan mengalami peningkatan.

Hipotesis pertama menyatakan bahwa Pajak Daerah berpengaruh positif terhadap Kemampuan Keuangan Daerah Daerah dapat di terima. Hasil penelitian ini sejalan dengan pendapat yang di kemukakan Dedy (2009) Perubahan Atas Undang-undang Nomor 18 Tahun 1987 tentang Pajak Daerah dan Retribusi Daerah. Perubahan berbagai kebijakan nasional sebagaimana dimaksud membawa harapan besar bagi daerah untuk membangun daerahnya dengan menggali potensi daerahnya masing-masing sebagai sumber pendapatan daerah, khususnya pendapatan asli daerah. Harapan dari daerah tersebut merupakan hal yang wajar, karena diberikannya berbagai urusan pemerintahan sebagai urusan rumah tangganya dibarengi dengan muatan kewenangan untuk mengurus keuangannya secara otonom dalam membiayai penyelenggaraan otonomi, baik dalam menggali sumber-sumber keuangan, pemanfaatannya serta pertanggung jawabannya.

Menurut Undang-Undang Perpajakan Nasional, pengertian pajak merupakan iuran rakyat kepada negara berdasarkan undang-undang dengan tidak mendapat jasa timbal yang langsung dapat ditunjuk dan digunakan untuk membiayai pengeluaran umum dan pembangunan. Sedangkan pengertian pajak menurut Soeparman Soemahamidjaja dalam disertasinya yang berjudul "Pajak Berdasarkan Asas Gotong Royong" Universitas Padjadjaran Bandung 1964 sebagai berikut:

"Pajak adalah iuran wajib, berupa uang atau barang yang dipungut oleh penguasa berdasarkan norma-norma hukum, guna menutup biaya produksi barang-barang dan jasa-jasa kolektif dalam dalam mencapai kesejahteraan umum".

Lebih lanjut, pengertian pajak menurut (Mardiasmo, 2002) menyatakan bahwa pajak adalah iuran rakyat kepada kas negara berdasarkan undangundang (yang dapat dipaksakan) dengan tidak mendapat jasa timbal (kontraprestasi) yang langsung dapat ditunjukkan dan yang digunakan untuk membayar pengeluaran umum.

Dari definisi-definisi pajak di atas, dapat disimpulkan bahwa pajak memiliki unsur-unsur antara lain:

1. Iuran dari rakyat kepada negara Yang berhak memungut pajak hanyalah negara. Iuran tersebut berupa uang (bukan barang).

2. Berdasarkan undang-undang Pajak dipungut berdasarkan atau dengan kekuatan undang-undang serta peraturan pelaksanaannya. 
3. Tanpa jasa timbal atau kontraprestasi dari negara yang secara langsung dapat ditunjuk. Dalam pembayaran pajak tidak dapat ditunjukkan adanya kontraprestasi individu oleh pemerintah.

4. Untuk membiayai rumah tangga negara, yakni pengeluaran-pengeluaran yang bermanfaat bagi masyarakat luas

\subsubsection{Pengaruh Retribusi Daerah terhadap Kemampuan Keuangan Daerah Daerah.}

Berdasarkan hasil analisis dengan menggunakan perhitungan statistik, menunjukkan nilai koefisien regresi $\mathrm{X}_{2}$ terhadap $\mathrm{Y}$ sebesar 0,084 dengan $\mathrm{t}_{\text {hitung }}=$ 3.360 dan nilai signifikansi 0,654 lebih besar dari tingkat signifikansi alpa $=$ 0,05, hal ini berarti bahwa tidak terdapat pengaruh signifikan Retribusi Daerah terhadap Kemampuan Keuangan Daerah Daerah. Bahwa adanya pengaruh positif tersebut berarti semakin tinggi Retribusi Daerah, maka Kemampuan Keuangan Daerah Daerah akan mengalami peningkatan.

Hipotesis kedua menyatakan bahwa Retribusi Daerah berpengaruh positif terhadap Kemampuan Keuangan Daerah Daerah di tolak. Retribusi daerah menurut UU No 34 tahun 2000 adalah pungutan daerah sebagai pembayaran atas jasa atau pemberian ijin tertentu yang khusus disediakan dan/atau diberikan oleh pemerintah daerah untuk kepentingan orang pribadi atau badan. Sama dengan pajak daerah, retribusi daerah juga berpengaruh positif terhadap Kemampuan Keuangan Daerah daerah.

\section{KESIMPULAN}

Berdasarkan hasil penelitian dan pembahasan dapat disimpulkan bahwa: (1). Hasil pengujian regresi sederhana menunjukkkan nilai $R$ square sebesar 0,085 atau $8,5 \%$ menunjukkan bahwa variabel independen pajak daerah, retribusi daerah, hanya dapat menjelaskan $8,5 \%$ perubahan Kemampuan Keungan Daerah. Sedangkan sisanya sebesar 91,5\% dijelaskan oleh variabel lain yang tidak dimasukkan dalam model regresi pada penelitian ini. Nilai $R$ Square yang kecil, menunjukkan rendahnya kemampuan variabel independen dalam Mempengaruhi variasi varibel dependen.

(2). Melalui uji t dapat diketahui bahwa dari dua variabel ( pajak daerah, retribusi daerah,) memiliki probabilitas signifikansi diatas 0,05 yaitu $(0,271$, dan 0,084). dari sini dapat disimpulkan Kemampuan Keungan Daerah tidak dipengaruhi oleh kedua variabel independen yang diteliti..

(3). Melalui uji F dapat diketahui bahwa variabel pajak daerah, retribusi daerahsecara signifikan tidak berpengaruh terhadap Kemampuan Keungan Daerah. Hasil ini terlihat dari nilai signifikansi sebesar 0,302 (>0,05).

\section{DAFTAR PUSTAKA}

Adriansyah, 2003. Perimbangan Keuangan Pusat dan Daerah dalam Kerangka Pelaksanaan Otda.

Afriani, Ester, 2007. Pajak Daerah, Retribusi Daerah, Penerimaan Daerah, dan Pendapatan Asli Daerah (PAD), Medan.

Erlina, Sri Mulyani, 2007. Metedologi Penelitian Bisnis, USU press, Medan

Ghozali, Imam, 2005. Aplikasi Analisis Multivariate dengan Program SPSS, Badan Penerbit Universitas Diponegoro, Semarang.

Halim, Abdul. 2004. Akuntansi Sektor Publik Akuntansi Keuangan Daerah, Jakarta, Salemba Empat. 
Halim, Abdul dan Jamal A. Nasir, 2006. Kajian tentang keuangan daerah pemerintah kota Malang. Majalah Manajemen Usahawan Indonesia. No. 06/TH. XXXV.

Habirono, Haryo, 2002. Perda VS Aspirasi Masyarakat, Jakarta.

Hoessein, Bhenyamin, 2002. Perspektif Jangka Panjang Desentralisasi dan Otda. Honein, Asri, 2003. Evaluasi Perda Pajak dan Retribusi, Jakarta.

HR, Syaukani, Political Will Pusat Masih Sangat Rendah Untuk Implementasi Otda, KPPOD News Edisi Oktober 2003.

Ismail, Munawar, 2002. Pendapatan Asli Daerah dalam Otonomi Daerah.

Ismail, Tjip, 2002. Kebijakan Pajak Daerah dan Retribusi Daerah, Jakarta.

Jogiyanto, 2004. Metode Penelitian Bisnis Salah Kaprah dan Penglamanpengalaman, cetakan pertama, BPFE Yogyakarta, Yogyakarta.

Noor, Slamet B., 1998. Kamus Akuntansi, cetakan kelima, Grafika Sejahtera Offset, Jakarta.

Nur Indriantoro dan Bambang Supomo. 2002. Metode Penelitian Bisnis.Edisi Pertama, BPFE, Yogyakarta.

Republik Indonesia, UU No 32 tahun 2004 tentang Perubahan atas UU No 22 tahun 1999 tentang Pemerintahan Daerah.

Republik Indonesia, UU No 33 tahun 2004 tentang Perubahan atas UU No 25 tahun 1999 tentang Perimbangan antara Pusat dan Daerah.

Republik Indonesia, UU No 34 tahun 2000 tentang Perubahan atas UU No 18 tahun 1997 tentang Pajak dan Retribuís Daerah.

Siahaan, Marihot P., 2005. Pajak daerah \& retribusi daerah, Raja Grafindo Persada, Jakarta.

Sidik, Machfud, 2002. Implementasi UU No 25 tahun 1999 tentang Perimbangan Keuangan Pusat dan Daerah, Jakarta.

Sugiyono, 2006. Statistika untuk Penelitian, cetakan kesembilan, Alfa Beta, Bandung.

Umar, Husein, 2001. Riset Akuntansi: Metode Riset Sebagai Cara Penelitian Ilmiah, Gramedia Pustaka Utama, Jakarta.

Umar, Husein, 2003. Metode Riset Akuntansi Terapan, cetakan pertama, Ghalia Indonesia, Jakarta.

Yaya Jakaria, dan Parwanto, 2005. Komputansi Analisis Jalur dengan SPSS, Jakarta.

Fakultas Ekonomi Universitas Sumatera Utara Jurusan Akuntansi, 2004. Buku Petunjuk Teknis Penulisan Proposal Penelitian dan Penulisan Skripsi, Medan.

DJPKPD, 2004. Tinjauan Pelaksanaan Hubungan Keuangan Pusat dan Daerah $2001-2003$.

DJPKPD, Bunga Rampai Desentralisasi Fiskal, tahun 2004.

www.djpkpd.go.id

www.sumut.bps.go.id

www.djpk.depkeu.go.id 